\title{
Bacterioplankton dynamics in a subtropical estuary: evidence for substrate limitation
}

\author{
Michael C. Murrell* \\ US Environmental Protection Agency, National Health and Environmental Effects Research Laboratory, \\ Gulf Ecology Division, 1 Sabine Island Drive, Gulf Breeze, Florida 32561, USA
}

\begin{abstract}
Bacterioplankton abundance and metabolic characteristics were measured along a transect in Pensacola Bay, Florida, USA, to examine the factors that control microbial water column processes in this subtropical estuary. The microbial measures included ${ }^{3} \mathrm{H}$-L-leucine incorporation, ectoenzyme activity (aminopeptidase, $\alpha$-D-glucosidase, $\beta$-D-glucosidase) and bacterial abundance. Bacterioplankton abundance ranged from 1.8 to $15.3 \times 10^{9} \mathrm{l}^{-1}$ (average: $6.2 \times 10^{6}$ ); highest abundances occurred during summer months, particularly in the upper estuary. Bacterial secondary

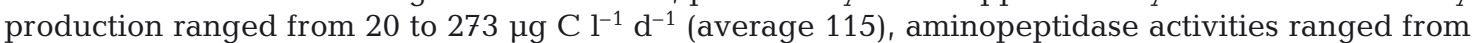
34 to $356 \mathrm{nmol} \mathrm{l}^{-1} \mathrm{~d}^{-1}$ (average 165), $\alpha$-D-glucosidase ranged from 0.4 to $61 \mathrm{nmol} \mathrm{l}^{-1} \mathrm{~d}^{-1}$ (average: 8.3), and $\beta$-D-glucosidase ranged from 1.4 to $53.1 \mathrm{nmol}^{-1} \mathrm{~d}^{-1}$ (average: 10.5). Bacterioplankton exhibited strong seasonality, suggesting that temperature was an important driver of the observed variability. When normalized for bacterial biomass, metabolic rates exhibited a striking inter-annual pattern with lower rates during summer 2000 than 2001. This pattern was consistent with freshwater flows, which were much lower during 2000 than 2001, consequently lowering nutrient and dissolved organic carbon (DOC) supply to the estuary. These results underscore the importance of riverine flux of materials to support bacterial metabolism and suggest that bacterioplankton were substrate-limited during the low flow period. The empirical relationships between bacterioplankton and phytoplankton variables were similar to those found in literature synthesis studies, with the notable exception that bacterial abundances and production were higher than predicted from chlorophyll a concentration. One explanation for this departure is that these relationships are drawn largely from cool temperate environments and warm subtropical systems are underrepresented in the literature.
\end{abstract}

KEY WORDS: Leucine incorporation · Ectoenzyme activity · Pensacola Bay · Gulf of Mexico Resale or republication not permitted without written consent of the publisher

\section{INTRODUCTION}

Bacterioplankton production and metabolic activities are critically important in structuring aquatic environments. Microbial processes mediate the biogeochemistry of critical life elements, such as carbon, oxygen, nitrogen, phosphorus, sulfur and other trace elements (Kirchman 2000). Bacterioplankton can also be an important link to the microbial food web by converting detrital carbon into biomass (Azam et al. 1983). Bacteria play a key role in decomposing autochthonous and allochthonous organic matter; a process that places a respiratory oxygen demand on the water column. In coastal and estuarine systems, oxygen demand in- creases with increased carbon loading, and coupled with stratification and warm temperatures, can result in hypoxic or anoxic bottom waters (NRC 2000). In this light, a better understanding of the linkages between organic carbon delivery and its microbial decomposition are critical to predicting oxygen demand and its ecosystem consequences. Therefore, examining bacterioplankton production, and its controlling factors, helps to develop a better functional understanding of aquatic systems.

Cross-system comparisons examining the linkage between phytoplankton and bacterioplankton production have found a remarkably robust empirical relationship that suggests bacterioplankton production 
typically comprises from 20 to $40 \%$ of phytoplankton production (Bird \& Kalff 1984, Cole et al. 1988). This implies a broad coupling between phytoplankton and bacterioplankton production; however, this coupling may be weaker in systems with large allochthonous inputs (Painchaud \& Therriault 1989, Findlay et al. 1991, Murrell et al. 1999). Also, the degree of coupling appears to be dependent on the temperature regime. For example, in arctic environments, bacterioplankton metabolism is temperature-limited, hence insensitive to changes in phytoplankton carbon sources (Pomeroy \& Wiebe 2001). Relatively little is known about the nature of this coupling in warm subtropical environments, such as the Gulf of Mexico.

The existing literature on bacterial production in Gulf of Mexico coastal and estuarine waters is focused on the very productive Mississippi River plume region as well as oligotrophic Gulf sites (Chin-Leo \& Benner 1992, Cotner \& Gardner 1993, Biddanda et al. 1994,

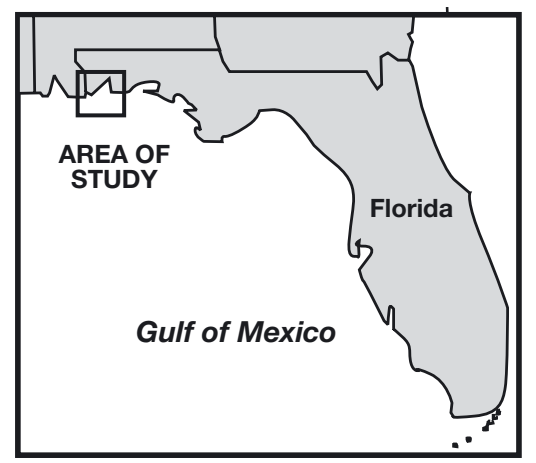

Fig. 1. Study area. Pensacola Bay, located in northwestern Florida, USA

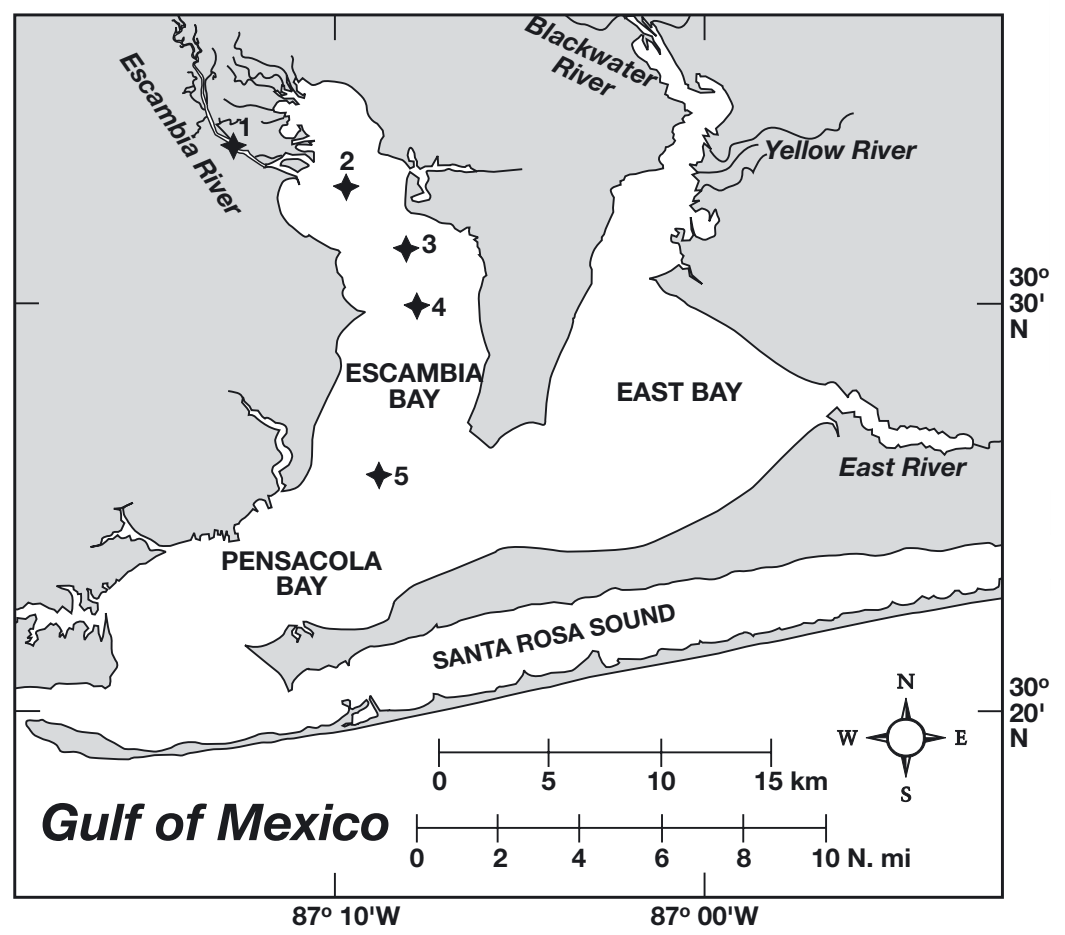

Pakulski et al. 1995, Pomeroy et al. 1995). Bacterial production rates from these regions range from 1 to $90 \mathrm{ug} \mathrm{Cl}^{-1} \mathrm{~d}^{-1}$ and appear to vary along trophic gradients. One study conducted in Santa Rosa Sound Florida (near the present study), found that bacterial production ranged from 0 to $66 \mu \mathrm{g} \mathrm{C} \mathrm{l}^{-1} \mathrm{~d}^{-1}$, being highest during summer and lowest during winter (Coffin \& Connolly 1997). The purpose of this study was to investigate the patterns of bacterioplankton metabolism in a warm subtropical estuarine system, and to evaluate the relative importance of autochthonous and allochthonous substrate sources. A further goal was to compare the results to widely cited literature-synthesis studies.

\section{MATERIALS AND METHODS}

Study site. Pensacola Bay is a moderately sized $\left(370 \mathrm{~km}^{2}\right)$ estuary located in northwestern Florida (Fig. 1), a micro-tidal, partially stratified, drowned river valley estuary (Schroeder \& Wiseman 1999). Tides are mixed but are predominately diurnal with a mean amplitude of $0.5 \mathrm{~m}$. About $80 \%$ of the freshwater in the system flows into the western side of the system from the Escambia River, which empties into Escambia Bay (Olinger et al. 1975), with an annual mean discharge of ca. $200 \mathrm{~m}^{3} \mathrm{~s}^{-1}$. The other $20 \%$ of the freshwater flow comes from the Blackwater, Yellow and East Rivers, which empty into the East Bay. The Escambia River is alluvial with a watershed area of $9900 \mathrm{~km}^{2}$, draining a landscape of pine forests $(74 \%)$, croplands $(12 \%)$, pastures $(7 \%)$ and urban development $(2 \%)$. River concentrations of dissolved inorganic nitrogen (DIN) averages $39 \mu \mathrm{M}$ (range: 14 to 107 ) and dissolved inorganic phosphorus (DIP) averages $1.2 \mu \mathrm{M}$ (range: 0.3 to 4.8 ) (Alexander et al. 1996). Escambia and East Bays converge into Pensacola Bay proper, which exchanges with the Gulf of Mexico through a narrow, deep pass at the western end of Pensacola Bay and Santa Rosa Sound. The mean water residence time for the entire system is about $25 \mathrm{~d}$ (Solis \& Powell 1999). Mean depths for Escambia Bay (Upper Bay) and Pensacola Bay proper (Lower Bay) are 2.4 and $5.9 \mathrm{~m}$, respectively (Olinger et al. 1975). Chl a concentra-

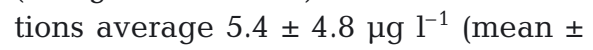
$\mathrm{SD})$ based on 5 yr quarterly data from 39 sites in Pensacola Bay and bottom waters can become hypoxic during 
summer months (J. Macauley unpubl. data). This study was focused along a transect of Escambia Bay because it receives the majority of the freshwater flow.

Water sampling and processing. Samples were collected on 23 dates from June 99 through November 2001. On each date, 5 sites were sampled ranging from the Escambia River to the Pensacola Bay region (Fig. 1). Hydrographic profile data were collected using a Hydrolab multi-meter (Table 1). Surface water was collected in clean polyethylene or polycarbonate bottles for transport to the laboratory where samples were processed within 2 to $3 \mathrm{~h}$ of collection. Water quality measures included chl $a$, particulate organic carbon (POC), particulate organic nitrogen (PON), dissolved organic carbon (DOC) and bacterial abundance. Metabolic measures included L-leucine incorporation and ectoenzyme activities of $\alpha$-D-glucosidase (Agluc), $\beta$-D-glucosidase (Bgluc) and aminopeptidase (Apep). Ectoenzyme activities were only measured during 1999 to 2000. Water flow data from the Escambia River were obtained from the United States Geological Survey gauging station at Century, FL, that is $56 \mathrm{~km}$ upstream from the mouth.

For chl $a$, water samples were filtered onto Whatman $\mathrm{GF} / \mathrm{F}$ filters and stored frozen at $-70^{\circ} \mathrm{C}$. The filters were methanol-extracted, sonicated using a Vibra Cell ${ }^{\circledR}$ probe (Jeffrey et al. 1997), and fluorescence was measured on a Turner Designs ${ }^{\circledR}$ Model TD700 fluorometer using filter sets recommended by Welschmeyer (1994). POC/PON samples were filtered onto pre-combusted $\left(500^{\circ} \mathrm{C}, 4 \mathrm{~h}\right) 25 \mathrm{~mm}$ Whatman $\mathrm{GF} / \mathrm{F}$ filters and the filtrate was collected in combusted vials for DOC analysis. DOC samples were stored at $-70^{\circ} \mathrm{C}$, and the POC/PON filters were dried and stored in a desiccator until analysis. DOC samples were analyzed with a Shimadzu TOC 5050 carbon analyzer standardized with potassium hydrogen phthalate. POC/PON samples were measured with a Carlo Erba 1500 carbon analyzer standardized with acetanilide.

Samples for bacterial abundance were fixed with $0.2 \mu \mathrm{m}$ pre-filtered formaldehyde at $2 \%$ final concentration. Within 1 or $2 \mathrm{~d}$ of collection, samples were stained with DAPI (1 $\mu \mathrm{g} \mathrm{ml} \mathrm{m}^{-1}$ final concentration), filtered onto black, $0.2 \mu \mathrm{m}$ polycarbonate membrane filters, mounted on microscope slides between layers of immersion oil, and counted using a UV filter combination (350 to $360 \mathrm{~nm}$ excitation, $>400 \mathrm{~nm}$ emission) on a Nikon Microphot epifluorescence microscope at 1250× (Porter \& Feig 1980). A minimum of 300 cells were counted, distributed over at least 10 microscope fields (typically 20 to 40). Duplicate samples were periodically counted and the coefficient of variation among replicates averaged $6.8 \%(n=25)$. Cyanobacteria often comprised a significant proportion of DAPI positive

Table 1. Hydrographic conditions averaged over the 5 sampling stations during the study period. DOC is dissolved organic carbon, and POC and PON are particulate organic carbon and nitrogen, respectively. The POC:PON is a molar ratio. DIN (dissolved inorganic nitrogen) is the sum of $\mathrm{NO}_{2}, \mathrm{NO}_{3}$ and $\mathrm{NH}_{4}$, and DIP is dissolved inorganic phosphorus

\begin{tabular}{|c|c|c|c|c|c|c|c|c|c|}
\hline Date & $\begin{array}{c}\text { Temperature } \\
\left({ }^{\circ} \mathrm{C}\right)\end{array}$ & $\begin{array}{l}\text { Salinity } \\
\text { (psu) }\end{array}$ & $\begin{array}{c}\mathrm{Chl} \mathrm{a} \\
\left(\mu \mathrm{g} \mathrm{l}^{-1}\right)\end{array}$ & $\begin{array}{c}\mathrm{DOC} \\
\left(\mathrm{mg} \mathrm{l}^{-1}\right)\end{array}$ & $\begin{array}{c}\mathrm{POC} \\
\left(\mathrm{mg} \mathrm{l}^{-1}\right)\end{array}$ & $\begin{array}{c}\text { PON } \\
\left(\mathrm{mg} \mathrm{l}^{-1}\right)\end{array}$ & PC:PN & $\begin{array}{l}\text { DIN } \\
(\mu \mathrm{M})\end{array}$ & $\begin{array}{c}\text { DIP } \\
(\mu \mathrm{M})\end{array}$ \\
\hline 30 Jun 99 & 28.0 & 7.4 & 7.4 & 4.9 & 0.8 & 0.1 & 6.6 & 7.6 & 0.4 \\
\hline 3 Aug 99 & 31.0 & 6.2 & 10.1 & 6.1 & 1.1 & 0.1 & 8.1 & 9.1 & 0.3 \\
\hline 9 Nov 99 & 19.1 & 18.0 & 2.9 & 3.4 & 0.5 & 0.1 & 7.4 & 4.7 & 0.2 \\
\hline 7 Dec 99 & 13.9 & 18.4 & 3.8 & 2.6 & 0.6 & & & 16.5 & 0.5 \\
\hline 9 Feb 00 & 10.9 & 14.7 & 4.1 & 2.8 & 0.7 & 0.1 & 9.0 & 9.8 & 0.4 \\
\hline 13 Mar 00 & 17.7 & 14.6 & 4.9 & 2.8 & 0.6 & 0.1 & 8.4 & 9.3 & 0.4 \\
\hline 12 Apr 00 & 20.0 & 10.2 & 7.7 & 4.4 & 0.8 & 0.1 & 8.1 & 8.3 & 0.4 \\
\hline 9 May 00 & 26.1 & 14.1 & 5.5 & 4.3 & 0.8 & 0.1 & 6.8 & 5.0 & 0.4 \\
\hline 13 Jun 00 & 29.0 & 20.4 & 6.7 & 3.3 & 0.8 & 0.1 & 7.0 & 5.7 & 0.4 \\
\hline 11 Jul 00 & 31.0 & 16.5 & 7.3 & 3.3 & 1.2 & 0.2 & 6.9 & 6.2 & 0.5 \\
\hline 15 Aug 00 & 29.5 & 17.4 & 6.6 & 3.3 & 1.1 & 0.2 & 7.1 & 6.6 & 0.5 \\
\hline 12 Sep 00 & 28.0 & 18.1 & 5.5 & 3.3 & 0.9 & 0.1 & 7.5 & 7.2 & 0.4 \\
\hline 18 Oct 00 & 21.8 & 21.5 & 2.9 & 2.8 & 0.8 & 0.1 & 10.5 & 5.9 & 0.2 \\
\hline 16 Jan 01 & 11.1 & 15.1 & 4.0 & & 0.6 & 0.1 & 7.2 & 10.6 & 0.1 \\
\hline 13 Mar 01 & 15.8 & 1.2 & 1.1 & & 1.4 & 0.2 & 9.6 & 5.1 & 0.2 \\
\hline 10 Apr 01 & 23.7 & 2.4 & 7.2 & & 0.9 & 0.1 & 8.1 & 7.6 & 0.3 \\
\hline 8 May 01 & 25.1 & 12.6 & 7.7 & & 1.0 & 0.2 & 6.2 & 3.4 & 0.0 \\
\hline 13 Jun 01 & 27.0 & 9.3 & 15.9 & & 1.2 & 0.2 & 7.4 & 4.8 & 0.1 \\
\hline $10 \mathrm{Jul} 01$ & 29.4 & 8.3 & 12.0 & & 1.1 & 0.2 & 5.7 & 5.0 & 0.1 \\
\hline 8 Aug 01 & 28.6 & 8.2 & 11.2 & & & & & 4.0 & 0.1 \\
\hline 11 Sep 01 & 27.9 & 7.9 & 10.4 & & 1.0 & 0.2 & 7.7 & 3.7 & 0.1 \\
\hline 16 Oct 01 & 22.7 & 17.6 & 9.2 & & 0.6 & 0.2 & 6.1 & 6.7 & 0.1 \\
\hline Average & 23.5 & 12.7 & 7.0 & 3.6 & 0.9 & 0.1 & 7.6 & 6.9 & 0.3 \\
\hline $\mathrm{SD}$ & 6.4 & 5.7 & 3.5 & 1.0 & 0.2 & 0.0 & 1.2 & 2.9 & 0.2 \\
\hline
\end{tabular}


cells (during summer months), so cyanobacteria were enumerated separately under green excitation (510 to $560 \mathrm{~nm}$ excitation, $>590 \mathrm{~nm}$ emission) and their abundance was subtracted from total DAPI positive cells to yield bacterioplankton abundance.

Bacterial productivity was determined by the incorporation of 4,5-[ $\left.{ }^{3} \mathrm{H}\right]$-L-leucine into cold TCA/ethanol insoluble pools following established methods (Hollibaugh \& Wong 1992, Smith \& Azam 1992, Murrell et al. 1999). During 2000, triplicate $5 \mathrm{ml}$ samples were incubated with added L-leucine $\left(5 \mathrm{Ci} \mathrm{mmol}^{-1}, 100 \mathrm{nM}\right.$ final concentration) for ca. $1 \mathrm{~h}$ at in situ temperature. Samples were filtered onto $0.45 \mu \mathrm{m}$ pore size Millipore ${ }^{\circledR}$ HA filters and sequentially rinsed with iced, unlabelled sample water, iced 5\% TCA and iced $80 \%$ ethanol to precipitate proteins and rinse away unincorporated label. The filters were placed into scintillation vials with $5 \mathrm{ml}$ of Packard Filter Count scintillation cocktail and assayed for radioactivity with a Packard TR 2500 liquid scintillation analyzer using transformed spectral index quench correction. During 2001, the volumes were scaled down to $1 \mathrm{ml}$, and protein was separated from unincorporated label by centrifugation following the methods of Smith \& Azam (1992). When both methods were applied simultaneously during the April and May 2001, the results were statistically indistinguishable (paired $t$-test, $\mathrm{p}>0.2$, data not shown) and the calculated rates from the 2 methods were averaged.

Several experiments were conducted to examine blank incorporation of radiolabel by including additional samples that were filtered immediately upon adding isotope (time 0 control) or fixed with formalin prior to isotope addition (killed control). These experiments showed that the radiolabel attributable to abiotic adsorption was small and was considered negligible for incorporation rate calculations (data not shown).

Bacterial growth assays were conducted during 2000 to convert L-leucine incorporation into carbon production equivalents, as described in Hollibaugh \& Wong (1996). For this assay, water samples were incubated for 24 to $48 \mathrm{~h}$ in the dark at in situ temperature in polyethylene Whirlpak ${ }^{\circledR}$ bags. To minimize grazing losses, the water was first diluted 9:1 with $0.2 \mu \mathrm{m}$ filtered sample water. Ten ml subsamples were taken at 3 to 4 time points over a 24 to $48 \mathrm{~h}$ incubation period, fixed and counted as described above, except that samples were assigned via a blind randomization process to minimize the likelihood of investigator bias. Bacterial growth rates $\left(\mu, \mathrm{d}^{-1}\right)$ were calculated as the slope of the natural log of cell abundance versus time by linear regression analysis. These growth rates were combined with ambient cell abundance and short-term Lleucine incorporation rates to calculate a cellular yield factor (cells produced $\mathrm{mol}^{-1}$ L-leucine incorporated).
Cells were converted to carbon equivalents using $20 \mathrm{fgC} \mathrm{Cell}^{-1}$ (Lee \& Fuhrman 1987). Because the bioassay relates cellular yield to L-leucine incorporation, it obviates the need to apply an isotope dilution factor.

Ectoenzyme activity. Ectoenzyme activity was measured using fluorogenic substrate analogs that mimic naturally occurring substrates (Hoppe 1983). The substrates included methyl-coumarin-amido (MCA)leucine, methylumbelliferyl (MUF)- $\alpha$-D-glucoside and MUF- $\beta$-D-glucoside, and are hydrolized by aminopeptidase (Apep), $\alpha$-D-glucosidase (Agluc) and $\beta$-D-glucosidase (Bgluc), respectively. The fluorescent substrates were added at saturating concentrations; results from preliminary experiments showed that $100 \mu \mathrm{M}$ was sufficient for Agluc and Bgluc, while $50 \mu \mathrm{M}$ was sufficient for Apep. The rate of cleavage of the fluorescent substrate was measured using a Turner Designs TD700 fluorometer with a near UV lamp, a 300 to $400 \mathrm{~nm}$ excitation filter and a 410 to $600 \mathrm{~nm}$ emission filter. Assays were conducted in the dark at in situ temperature for 1 to $3 \mathrm{~h}$ (Apep) or 6 to $12 \mathrm{~h}$ (Agluc, Bgluc). The fluorometer was calibrated each time with MUF and MCA, taking care to match the matrix of the assay as described below. The early experiments (June and August 1999) were not replicated within station, but all the later experiments were done in duplicate or triplicate. The variability among replicate incubations was typically small (CV $\sim 5 \%)$.

During 1999, assays were conducted as described in Murrell et al. (1999), wherein sub-samples were fixed with alkaline buffer $(0.05 \mathrm{M}$ glycine, $0.2 \mathrm{M}$ $\mathrm{NH}_{4} \mathrm{OH}, \mathrm{pH}$ 10.3) prior to reading fluorescence. In 2000 , the assays were conducted at ambient $\mathrm{pH}$ without the alkaline buffer step. Matrix-matched standards were prepared from each sampling station to account for the variation in fluorescence yield due to $\mathrm{pH}$ effects (especially with MUF; however, not with MCA) and interference from dissolved substances. The MUF fluorescence yield varied on the order of 2fold, depending on the sampling station (decreasing with decreasing salinity). The fluorescence yield of MCA was more stable, varying by $10 \%$ among different stations.

Temperature adjustment. When necessary, the Arrhenius model was used to adjust measured metabolic rates. This occurred when the incubation temperature varied from ambient water temperature (usually a small adjustment), but this adjustment was also applied to normalize bacterioplankton metabolism to examine the role of other environmental factors. The Arrhenius equation is defined as:

$$
v=A \exp \left(-E_{\mathrm{a}} / \mathrm{R} T\right)
$$


where $v$ is the metabolic rate, $\mathrm{A}$ is a constant, $E_{\mathrm{a}}$ is the apparent energy of activation, $\mathrm{R}$ is the gas constant, and $T$ is temperature $\left({ }^{\circ} \mathrm{K}\right)\left(\mathrm{Li} \&\right.$ Dickie 1987). $Q_{10}$ is a commonly used index of metabolic temperature and is the ratio of metabolic rates at 2 temperatures $T_{2}$ and $T_{1}$ where $T_{2}=T_{1}+10 . Q_{10}$ relates to the above Arrhenius equation as follows:

$$
v_{2} / v_{1}=Q_{10}=\exp \left[E_{\mathrm{a}} / \mathrm{R}\left(T_{2}-T_{1}\right) / T_{2} T_{1}\right]
$$

A nominal $Q_{10}$ of 2.0 was assumed and $T_{1}=293^{\circ} \mathrm{K}$ $\left(20^{\circ} \mathrm{C}\right)$, then solving for $E_{\mathrm{a}} / \mathrm{R}$ yielded a value of 6361 , which was re-inserted into the above equation and solved for the metabolic rate $\left(v_{2}\right)$ adjusted to the desired temperature.

\section{RESULTS}

\section{Hydrographic conditions}

This study spanned a period that varied markedly in freshwater flow (Table 2). During June 1999, a shortterm pulse in river flow occurred due to a rain event, but following this point, there was very little rain and consequently, exceptionally low freshwater flow from the Escambia River for the following 15 mo. Beginning in Spring 2001, the flow regime returned to near-normal conditions. During the 2000 drought, flows were about $1 / 5$ of normal during the springsummer period. The annual average flow was $47 \mathrm{~m}^{3}$ $\mathrm{s}^{-1}$, or $74 \%$ below the $65 \mathrm{yr}$ average $\left(178 \mathrm{~m}^{3} \mathrm{~s}^{-1}\right)$ and $24 \%$ below the previous record low flow in 1968 $\left(62 \mathrm{~m}^{3} \mathrm{~s}^{-1}\right)$.

Average chl a concentrations varied from 1.1 to $15.9 \mu \mathrm{g} \mathrm{l}^{-1}$, generally being higher during summer months and with noticeable inter-annual variability
Table 2. Seasonally averaged flow $\left(\mathrm{m}^{3} \mathrm{~s}^{-1}\right)$ from the Escambia River. US Geological Survey data from the gauging station at Century, FL. Annual averages are included for each year and seasonal averages $( \pm \mathrm{SD})$ are included for the entire data record (1935 to 2001)

\begin{tabular}{|lrrrrc|}
\hline & Winter & Spring & Summer & Fall & Average \\
\hline 1999 & 204 & 125 & 143 & 53 & 131 \\
2000 & 84 & 48 & 22 & 35 & 47 \\
2001 & 266 & 260 & 115 & 72 & 178 \\
& & & & \\
Average & 273 & 229 & 107 & 101 & 178 \\
& \pm 62 & \pm 103 & \pm 19 & \pm 33 & \\
\hline
\end{tabular}

(Table 1). Summer peak concentrations typically occurred in the upper estuary (Stns 2 and 3, data not shown) and average chl a peaked at 7.3 and $15.9 \mathrm{\mu g}^{-1}$ in July 2000 and June 2001, respectively. As expected, chl a correlated positively with temperature and negatively with DIN concentrations ( $p<0.01$, Table 3 ).

DOC data were only available from 1999 to 2000 and ranged from 2.6 to $6.1 \mathrm{mg} \mathrm{l}^{-1}$ with a mean $( \pm \mathrm{SD})$ of $3.6 \pm 1.0$. In general, DOC was conservatively distributed along the salinity gradient (data not shown), being highest in the river and lower downstream. POC concentrations averaged $0.9 \pm 0.2 \mathrm{mg} \mathrm{l}^{-1}$. Both POC and PON covaried strongly with chl a concentrations (Table 3). The molar ratio of POC:PON averaged $7.6 \pm$ 1.2 and was slightly above the Redfield ratio (Redfield 1958) for phytoplankton (6.6), suggesting that particulate organic matter in this system was of relatively low detrital content. The average POC contribution to TOC was $20 \%$, which is also consistent with a planktonbased rather than a detrital-based system (Meybeck 1982).

Table 3. Pearson correlation matrix of log-transformed metabolic and environmental variables. The flux term was calculated as the $7 \mathrm{~d}$ average Escambia River flow multiplied by the freshwater content (33-Sal)/33. Leu: L-leucine incorporation; BAbun: bacterial abundance; Apep: aminopeptidase activity; Agluc: $\alpha$-D-glucosidase activity; Bgluc: $\beta$-D-glucosidase activity. For other abbreviations see Table 1. Significance: $p<0.05$ indicated by ${ }^{*} ; \mathrm{p}<0.01$ (in bold)

\begin{tabular}{|c|c|c|c|c|c|c|c|c|c|c|c|c|}
\hline & Leu & BAbun & Apep & Agluc & Bgluc & Temperature & Salinity & Chl a & POC & DOC & DIN & DIP \\
\hline BAbun & 0.59 & & & & & & & & & & & \\
\hline Apep & 0.59 & 0.59 & & & & & & & & & & \\
\hline Agluc & 0.76 & 0.68 & 0.61 & & & & & & & & & \\
\hline Bgluc & 0.82 & 0.58 & 0.40 & 0.62 & & & & & & & & \\
\hline Temp & 0.65 & 0.57 & 0.40 & 0.58 & 0.55 & & & & & & & \\
\hline Sal & -0.19 & -0.04 & 0.34 & 0.10 & -0.09 & -0.01 & & & & & & \\
\hline Chl a & 0.51 & 0.40 & 0.68 & 0.45 & 0.23 & 0.42 & 0.39 & & & & & \\
\hline POC & 0.65 & 0.65 & 0.70 & 0.55 & 0.37 & 0.36 & 0.01 & 0.53 & & & & \\
\hline DOC & 0.16 & 0.41 & 0.18 & $0.28^{*}$ & 0.19 & 0.40 & -0.63 & $0.28^{*}$ & $0.26^{*}$ & & & \\
\hline DIN & -0.04 & 0.00 & $-0.28^{*}$ & -0.03 & 0.15 & -0.29 & -0.47 & -0.32 & -0.25 & 0.35 & & \\
\hline DIP & -0.13 & 0.13 & -0.06 & 0.17 & 0.47 & 0.02 & -0.06 & -0.16 & 0.04 & 0.18 & 0.30 & \\
\hline Flux & 0.35 & 0.09 & -0.09 & -0.08 & -0.16 & -0.08 & -0.73 & -0.06 & 0.25 & 0.61 & 0.26 & -0.14 \\
\hline
\end{tabular}




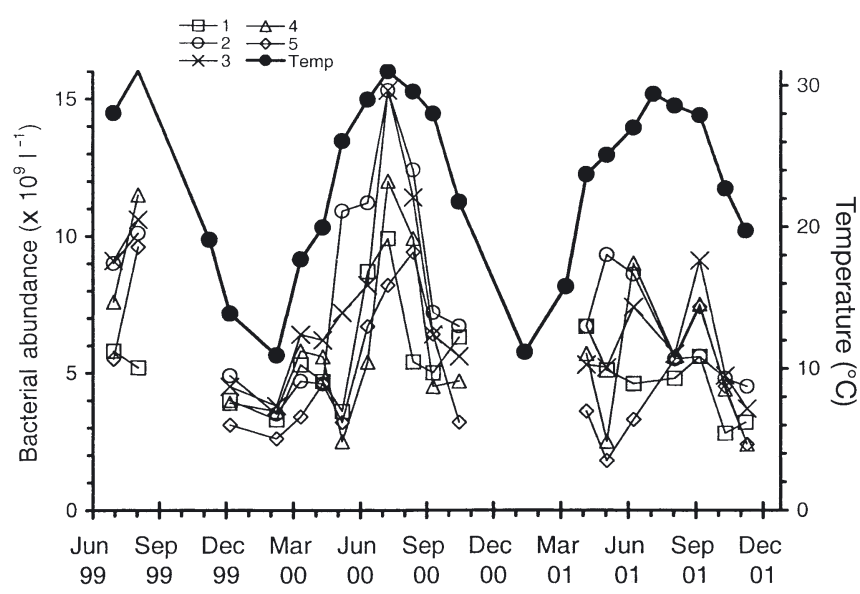

Fig. 2. Bacterial abundance at the 5 sites over the study period. Surface water temperature is depicted by the heavy line

\section{Bacterial abundance}

Bacterial abundances (Fig. 2) averaged $6.7 \times 10^{9}$

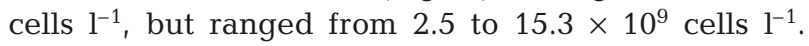
The upper estuarine sites (Stns 2 and 3) usually had the highest abundance, while the Escambia River (Stn 1) and Lower Bay site (Stn 5) had somewhat lower abundance. The most striking trend was the strong seasonal variation in bacterioplankton abundance during 2000, with highest abundances coinciding with peak summer temperatures; a pattern less pronounced during 2001. The seasonality is reflected by the strong positive correlations between temperature and bacterioplankton abundance and metabolism (Table 3).

\section{L-leucine incorporation and bacterial production}

Bacterioplankton growth rates derived from dilution bioassays were used to convert L-leucine incorporation rates into carbon production equivalents. Of the 35 bioassays conducted (5 Stns, 7 dates), 24 yielded measurable growth rates $\left(\mu \geq 0.01 \mathrm{~h}^{-1}\right)$. These growth rates were combined with cell abundance data to calculate cellular production rates (Fig. 3). Conversion factors varied from 0.63 to $5.3 \times 10^{17}{\text { cells } \mathrm{mol}^{-1} \mathrm{~L}-}^{-}$ leucine with no consistent spatial or temporal patterns (Fig. 3A). The mean conversion factor of $2.1 \pm 0.25$ (mean $\pm \mathrm{SE}$ ), the median of 1.8 and the regression slope of 2.2 (Fig. 3B) of a plot of cells produced versus L-leucine incorporation were all quite similar. Based on the convergence of these 3 estimates, a factor of $2.0 \times$ $10^{17}$ cells mol $^{-1}$ L-leucine was applied to incorporation rates and scaled to carbon using $20 \mathrm{fg} \mathrm{C}^{-1} \mathrm{cell}^{-1}$ (Lee \& Furhman 1987).
Bacterial secondary production (Fig. 4A) ranged from 20 to $273 \mu \mathrm{g} \mathrm{C} \mathrm{l}^{-1} \mathrm{~d}^{-1}$ and averaged $115 \mu \mathrm{g} \mathrm{Cl}^{-1} \mathrm{~d}^{-1}$ across all stations and dates. A strong seasonal signal was apparent, with peaks in productivity occurring during both summers; however, productivities were higher in 2001. On most dates, the highest bacterial production occurred in the upper estuary. Bacterialspecific growth rates (SGR, Fig. 4B) were calculated by combining the abundance and bulk productivity data and ranged from 0.3 to $2.7 \mathrm{~d}^{-1}$ (average $1.0 \mathrm{~d}^{-1}$ ). During 2000, SGR was noticeably lower than during 2001 and exhibited little seasonal variation. During 2001, SGR appeared to respond to seasonal variation in temperature; a feature conspicuously absent from the 2000 data. The inter-annual pattern in SGR was investigated further by normalizing to a constant temperature $\left(25^{\circ} \mathrm{C}\right)$, averaged by date and then examined in relation to freshwater flow (Fig. 5).

\section{Ectoenzyme activity}

Apep activity averaged 165 (range 34 to 356 ) $\mathrm{nmol} \mathrm{l}^{-1}$ $\mathrm{h}^{-1}$, with generally higher bulk rates during the
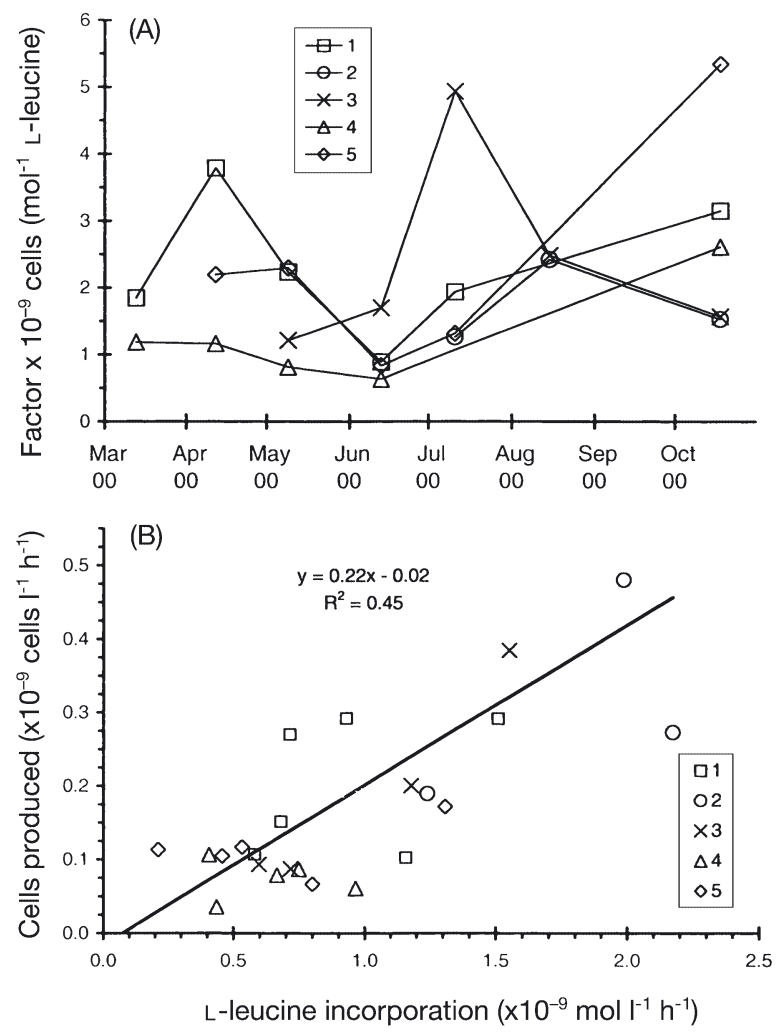

Fig. 3. (A) Spatial and temporal variability in bacterial production conversion factors. (B) Relationship between bacterial growth rates from dilution bioassays and L-leucine incorporation. Symbols indicate station 

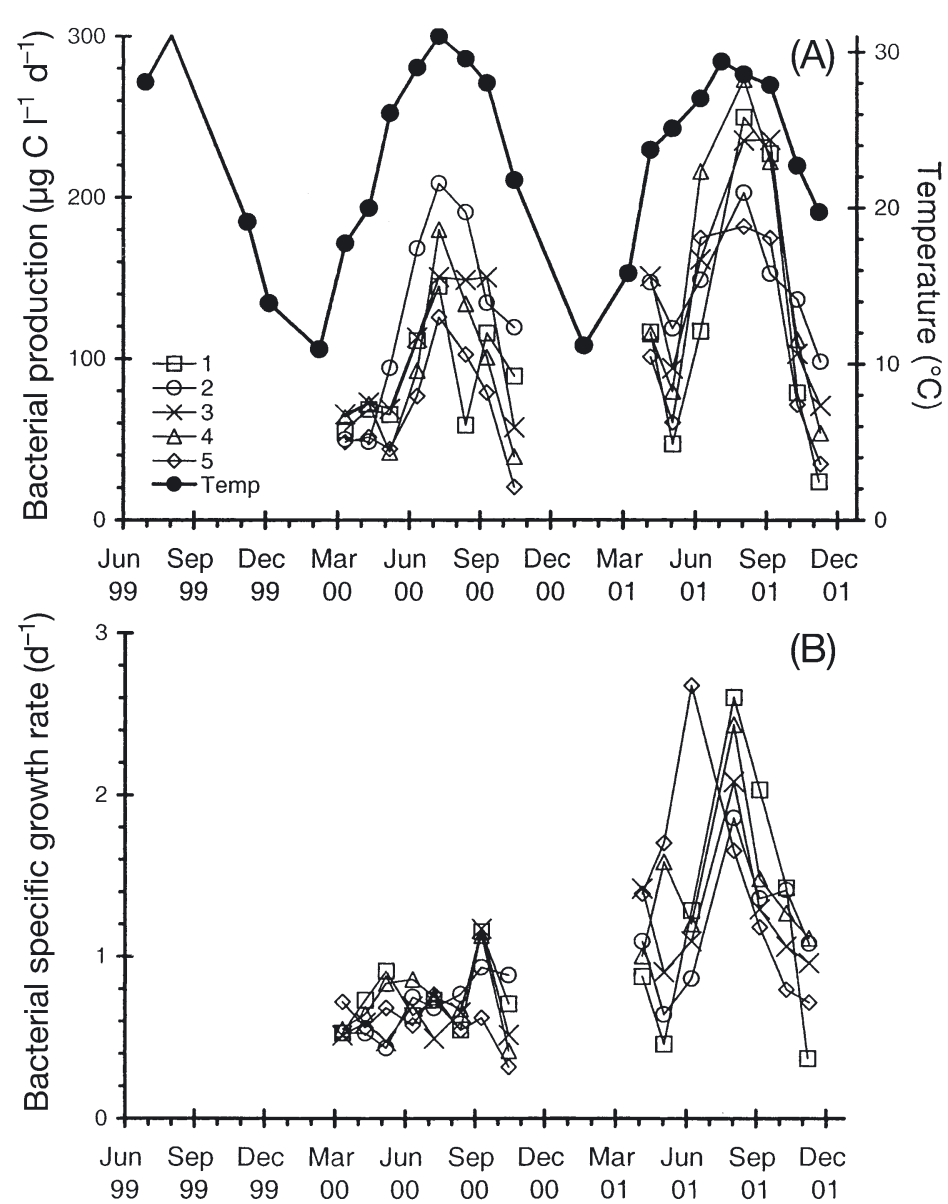

Fig. 4. (A) Bacterial production and (B) specific growth rate based on L-leucine incorporation assays at the 5 sites over the study period. Surface water temperature is depicted by the heavy line

summer (Fig. 6A). Similar to bacterial production, the upper estuary (Stn 2) tended to have the highest Apep activities; however, the seasonal pattern was less pronounced than with bacterial production. Agluc activities averaged $8.3 \mathrm{nmol} \mathrm{l^{-1 }} \mathrm{h}^{-1}$ (median: 5.7) but spanned more than 2 orders of magnitude $(0.4$ to $\left.60.5 \mathrm{nmol} \mathrm{l}^{-1} \mathrm{~h}^{-1}\right)$, and had strongly elevated rates during the summer (Fig. 6B). There was a gradient in Agluc activities, which tended to be higher in the upper estuary than in the lower estuary. A remarkable Agluc activity of $60.5 \mathrm{nmol} \mathrm{l}^{-1} \mathrm{~h}^{-1}$ was measured in September 2000 at the river site; more than 2-fold higher than the next highest activity. Bgluc activities averaged 10.4 (range: 1.4 to 53.1 ) $\mathrm{nmol}^{-1} \mathrm{~h}^{-1}$ (median: 8.4), again with a strongly elevated rates during the summer (Fig. 6C). As with Agluc, Bgluc activities were generally higher in the upper estuary than the lower estuary. There was also a single strong peak in Bgluc (53.1 $\mathrm{n} \mathrm{nmol}^{-1} \mathrm{~h}^{-1}$ ) at the river site, but it occurred 2 mo prior to the Agluc peak.

\section{DISCUSSION}

\section{Bacterioplankton production}

Bacterial production in Pensacola Bay averaged $115 \mu \mathrm{g} \mathrm{C}^{-1} \mathrm{~d}^{-1}$ (range: 20 to $273 \mu \mathrm{g} \mathrm{Cl}^{-1}$ $\mathrm{d}^{-1}$ ) well above the 50 to $73 \mu \mathrm{g} \mathrm{C} \mathrm{l}^{-1} \mathrm{~d}^{-1}$ range reported for estuaries in a review by Ducklow \& Carlson (1992). Bacterial production data for the Gulf of Mexico region are underrepresented in the literature, especially in estuarine environments. All published after Ducklow \& Carlson (1992), several studies have examined bacterioplankton in the Mississippi River plume and open Gulf waters (Chin-Leo \& Benner 1992, Cotner \& Gardner 1993, Biddanda et al. 1994, Pakulski et al. 1995, Pomeroy et al. 1995). Chin-Leo \& Benner (1992) found that bacterial production varied from 4 to $90 \mu \mathrm{g} \mathrm{Cl}^{-1} \mathrm{~d}^{-1}$ during summer and from 3 to $20 \mu \mathrm{g} \mathrm{C} \mathrm{l}^{-1} \mathrm{~d}^{-1}$ during winter. Cotner \& Gardner (1993) reported a summer range of 4.3 to $107 \mu \mathrm{g} \mathrm{C}^{-1} \mathrm{~d}^{-1}$, Pakulski et al. (1995) reported a

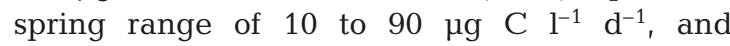
Biddanda et al. (1994) reported a fall range of 2.4 to $74 \mu \mathrm{g} \mathrm{C} \mathrm{l}^{-1} \mathrm{~d}^{-1}$. Pomeroy et al. (1995) measured a range of 0.7 to $28 \mu \mathrm{g} \mathrm{Cl}^{-1} \mathrm{~d}^{-1}$ during summer at mostly oligotrophic sites. Coffin \& Connolly (1997) found quite low bacterial production from 0 to $66 \mu \mathrm{g} \mathrm{Cl}^{-1} \mathrm{~d}^{-1}$ in Santa Rosa Sound, a system adjacent to the Pensacola Bay. Based on these reports, bacterioplankton production in Pensacola Bay is the highest reported from the Gulf of Mexico region.

The most productive sites in Pensacola Bay were in the upper estuary, near the mouth of the

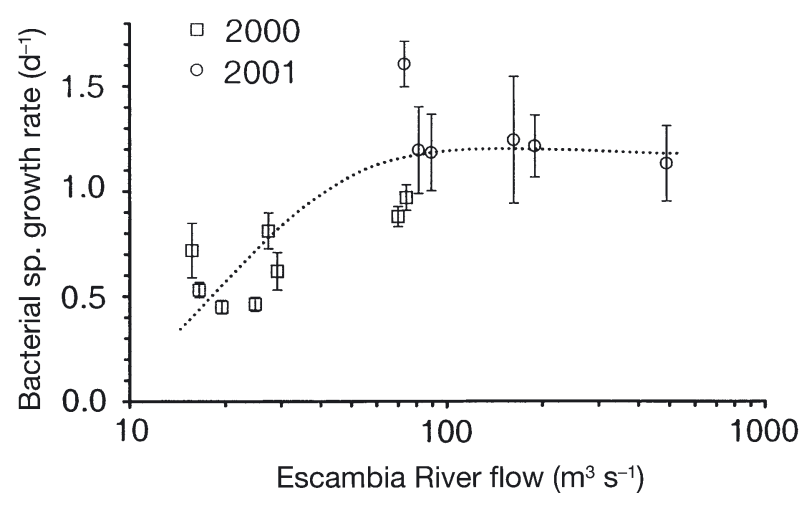

Fig. 5. Plot relating average bacterial specific growth rates to freshwater flow from the Escambia River. Specific growth rates were averaged by date and temperature-adjusted to $25^{\circ} \mathrm{C}$ assuming a $Q_{10}$ of 2 (see 'Materials and methods). Error bars represent the SE among stations on a given date 

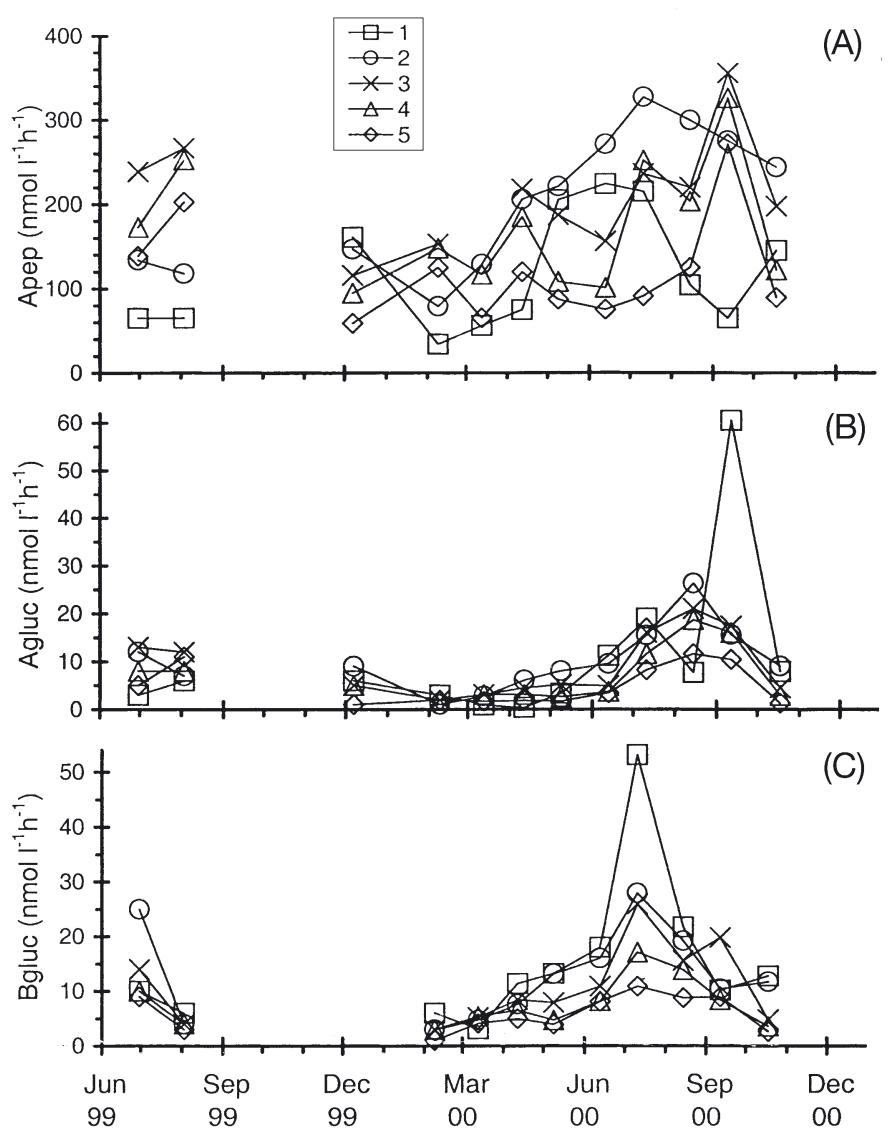

Fig. 6. Ectoenzyme activities measured at the 5 sites during 1999 and 2000. (A) Aminopeptidase, (B) $\alpha$-D-glucosidase and (C) $\beta$-D-glucosidase

Escambia River, an area also typified by peak chl a concentrations. This pattern is generally consistent with observed empirical relationships between bacterioplankton and phytoplankton biomass and productivity (Bird \& Kalff 1984, Cole et al. 1988, White et al. 1991) and supported by the positive correlations between bacterial metabolism and chl a concentrations (Table 3). Also, the upper estuary frequently exhibited higher ectoenzyme activities than the adjacent river and lower estuarine sites, particularly aminopeptidase (Fig. 6). This peak may simply reflect a microbial response to increased algal biomass, but also may be due to enhanced degradation of allochthonous organic matter by estuarine-dependent microbial communities. In estuaries with large allochthonous carbon inputs, the role of phytoplankton supporting bacterioplankton production may be diminished (Kirchman et al. 1989, Painchaud \& Therriault 1989, Findlay et al. 1991, Hollibaugh \& Wong 1996, Murrell et al. 1999). However, it appears that Pensacola Bay has relatively low allochthonous carbon inputs and, thus, microbial metabolism is probably driven by phytoplankton. This view is based on the relatively low POC:PON ratios and DOC concentrations (Table 1).

\section{Conversion factors}

A critical component of accurately estimating bacterioplankton production is applying appropriate conversion factors that relate radiolabel incorporation to cell and carbon production rates (Ducklow \& Carlson 1992, Ducklow 2000). In this study, a factor of $2.0 \times 10^{17}$ cells $\mathrm{mol}^{-1}$ L-leucine incorporated was used to scale leucine incorporation rates to cell-based production. While individual conversion factors ranged widely from 0.63 to $5.3 \times 10^{17}$ cells $\mathrm{mol}^{-1}$ L-leucine incorporated, they generally agree in magnitude and variation with similarly derived factors from other estuarine and coastal sites (Chin-Leo \& Kirchman 1988, Hollibaugh \& Wong 1996). This factor is in a sense an index of bacterial growth efficiency, which is influenced by environmental factors, such as temperature and substrate supply. One would expect conversion factors to vary in response to environmental conditions; however, the lack of clear spatial and temporal patterns (Fig. 3A) implies that other sources of error, such as measurement error, may be relatively more important. It is therefore likely that true conversion factors are less variable than suggested by measurements, and this provides the rationale for applying a single factor to the entire data set.

Using a completely different approach, Simon \& Azam (1989) derived a conversion factor, based on the relative protein and carbon content of bacterioplankton cells, which they argued to be quite stable. They reported a $7.3 \mathrm{~mol} \%$ L-leucine in bacterial protein and a 0.86 carbon:protein ratio, and recommended adopting an isotope dilution of 2. Combining these factors, Simon \& Azam (1989) recommended a factor of $3.1 \mathrm{~kg}$ $\mathrm{C}$ produced $\mathrm{mol}^{-1} \mathrm{~L}$-leucine incorporated. In this study (assuming $20 \mathrm{fg} \mathrm{C} \mathrm{cell}^{-1}$ ), the comparable factor was somewhat higher at $4.0 \mathrm{~kg} \mathrm{C}$ produced $\mathrm{mol}^{-1}$ L-leucine incorporated.

\section{L-leucine incorporation versus ectoenzyme activity}

Amino acid incorporation and the various ectoenzyme activities measure different processes, yet they all are metabolic indices of microbial activity. Amino acid incorporation integrates bacterial activities of membrane transport and translational assembly of proteins. Ectoenzyme activity, on the other hand, measures cell-surface expression of ectoenzymes and is a crucial microbial process because it breaks down poly- 
mers into smaller units that only then can be transported across the cell membrane (Hoppe 1983, Chrost 1990). In this manner, ectoenzyme activity may reflect the substrate environment in which the bacteria reside. Because both approaches measure aspects of bacterial metabolism, it is not surprising that, when measured simultaneously, they tend to correlate (Somville \& Billen 1983, Somville 1984, Vives-Rego et al. 1985, Rosso \& Azam 1987, Karner et al. 1992, Muller-Niklas et al. 1994, Murrell et al. 1999) as they do in this study (Table 3).

The variability in ectoenzyme activities suggested that they were a more sensitive and less integrative index of the microbial metabolism than L-leucine incorporation rates. The high variation was most evident at the river site, in July with Bgluc and September with Agluc, where rates were about double other respective measures. Glucosidase ectoenzymes are regulated by the availability their polymeric substrates as well as their respective monomers. As such, both the presence of polymers and the lack of monomers appear to up-regulate the expression of the ectoenzyme (Munster 1991). Therefore, the especially high glucosidase rates in the river imply either glucose limitation or a pulse of polysaccharides. However, given the transient nature of these spikes in activity, it is difficult to attach too much significance to these results.

\section{Role of river flow contributing to observed patterns}

A strong inter-annual pattern was evident in bacterioplankton production and abundance, especially when these variables were combined and plotted as specific growth rate (Fig. 4B). During 2000, specific growth rates averaged $0.7 \pm 0.2 \mathrm{~d}^{-1}( \pm \mathrm{SD})$ and varied little over the course of the summer, despite a large temperature excursion. In contrast, specific growth rates during 2001 averaged $1.4 \pm 0.6$ and exhibited strong seasonal variation. During 2001, SGR ranged from 0.5 to $2.5 \mathrm{~d}^{-1}$, a 5 -fold variation that coincided with a $20^{\circ} \mathrm{C}$ temperature change. A physiological mechanism for this variation appears likely given that, using a nominal $Q_{10}$ of 2, one would expect a 4 -fold change in SGR over this temperature range. In this light, the lack of any real temperature response during 2000, coinciding with the severe drought, strongly suggests that bacterioplankton were substrate-limited. The resumption of normal flows during 2001, apparently alleviated this limitation (Fig. 5). In systems with large allochthonous carbon inputs, such as the Hudson River estuary (Findlay et al. 1991), the St. Lawrence River (Painchaud \& Therriault 1989) and northern San Francisco Bay (Hollibaugh \& Wong 1996, Murrell et al. 1999), bacterioplankton production appears strongly linked to variation in fresh- water flow. One might conclude that bacterioplankton production was similarly controlled in Pensacola Bay; however, organic matter in Pensacola Bay appeared to be largely of phytoplankton origin as evidenced by low POC:PON ratios and DOC concentrations (Table 1). Therefore, it is more likely that the drought during 2000 reduced nutrient delivery and, consequently, reduced phytoplankton productivity, and this resulted in the patterns in specific growth rates observed. During 2001, specific growth rates were much higher, but the relationship between SGR and river flow appears to asymptote, near $1.5 \mathrm{~d}^{-1}$, implying that further increases freshwater flow may not result in further increases in specific growth.

\section{Empirical relationships between bacterioplankton and phytoplankton}

Several synthesis studies have examined the relationships between phytoplankton and bacterioplankton variables using data compiled from the literature and by performing simple regression analysis (Bird \& Kalff 1984, Cole et al. 1988, White et al. 1991). Together, these studies encompass a wide variety of marine, freshwater and estuarine systems; however, the data sources tend to be weighted to cool temperate regions. To place Pensacola Bay data into this context, identical regression analyses were performed to examine the degree of coupling between phytoplankton biomass (as chl a) and bacterioplankton biomass (as cell abundance) and production, as well as the coupling between bacterioplankton biomass and production. In all 3 cases, the regressions were highly significant $(p<0.001$, Table 4$)$, but had low $R$ square values. The relationship between $\mathrm{chl} a$ and bacterioplankton abundance (Fig. 7A) shows that the 2 literature studies (Bird \& Kalff 1984, Cole et al. 1988) had similar regressions; however, the Pensacola Bay data lie consistently above them. The Model I regression statistics suggest that both the slope and intercept were significantly different (Table 4). Also, bacterial production in Pensacola Bay was greater than predicted by chl a (Fig. 7B) from both Cole et al. (1988) and White et al. (1991). The plot relating bacterial abundance to bacterial production (Fig. 7C) was mixed, showing that bacterioplankton production fell well below that predicted from abundance by White et al. (1991), and were somewhat higher than Cole et al. (1988). In this case, the 2 literature studies varied wildly in the intercept estimate, but had similar slopes.

This analysis suggests that bacterial abundance and production were considerably higher in Pensacola Bay than expected from the chl a concentrations; a difference that approached an order of magnitude when 
Table 4. Regression statistics describing relationships between log-transformed bacterioplankton and phytoplankton variables, including bacterial abundance (BAbun, cells ml $\left.{ }^{-1}\right)$, chorophyll ( $\mathrm{chl} a, \mu \mathrm{gl}^{-1}$ ) and bacterial production $\left(\mathrm{BProd}_{1} \mu \mathrm{g} \mathrm{Cl}^{-1} \mathrm{~d}^{-1}\right)$. In all cases, $p$-values from the $F$-test were $<0.0001$. Confidence limits for regression parameter estimates were included and adjusted to $95 \%$ if reported differently in the source. Confidence limits around predicted values of Y can be calculated using mean X and corrected sums of square X (SSX). The residual mean square can be calculated from the correction factor. The correction factor must be used when converting from log to arithmetic scales; this factor corrects for an inherent bias of log-transformed regressions. The Model II slope is an estimate of the true relation between X and Y when there is error in the independent variable.

Y-int: $y$-intercept. na: not available

\begin{tabular}{|c|c|c|c|c|c|c|c|c|c|}
\hline Source & $\mathrm{Y}, \mathrm{X}$ & $\mathrm{n}$ & Slope $(95 \%$ CI) & Y-int $(95 \%$ CI) & $\mathrm{R}^{2}$ & Mean X & SSX & $\mathrm{CF}$ & Model II slope \\
\hline Bird \& Kalff (1984) & BAbun, chl a & 39 & $0.78( \pm 0.09)$ & $5.87( \pm 0.07)$ & 0.88 & 0.38 & 23.0 & 1.11 & 0.83 \\
\hline Cole et al. (1988) & BAbun, chl a & 35 & $0.52( \pm 0.14)$ & 5.89 na & 0.75 & 0.96 & 17.8 & 1.14 & 0.60 \\
\hline This study & BAbun, chl a & 95 & $0.23( \pm 0.11)$ & $6.57( \pm 0.09)$ & 0.15 & 0.76 & 10.0 & 1.15 & 0.60 \\
\hline Cole et al. (1988) & BProd, chl a & 41 & $0.62( \pm 0.18)$ & 0.35 na & 0.62 & 0.87 & 24.0 & 1.59 & 0.82 \\
\hline White et al. (1991) & BProd, chl a & 412 & $0.71( \pm 0.09)$ & $0.86( \pm 0.09)$ & 0.36 & 0.68 & 205.1 & 3.23 & 1.18 \\
\hline This study & BProd, chl a & 75 & $0.39( \pm 0.15)$ & $1.57( \pm 0.12)$ & 0.26 & 0.77 & 8.0 & 1.34 & 0.76 \\
\hline Cole et al. (1988) & BProd, Babun & 40 & $1.12( \pm 0.42)$ & -6.08 na & 0.63 & 6.45 & 7.4 & 4.46 & 1.41 \\
\hline White et al. (1991) & BProd, Babun & 700 & $1.22( \pm 0.06)$ & $0.89( \pm 0.05)$ & 0.68 & 0.24 & 439.3 & 3.33 & 1.48 \\
\hline This study & BProd, Babun & 75 & $0.75( \pm 0.24)$ & $-3.20( \pm 1.61)$ & 0.34 & 6.75 & 3.6 & 1.27 & 1.27 \\
\hline
\end{tabular}
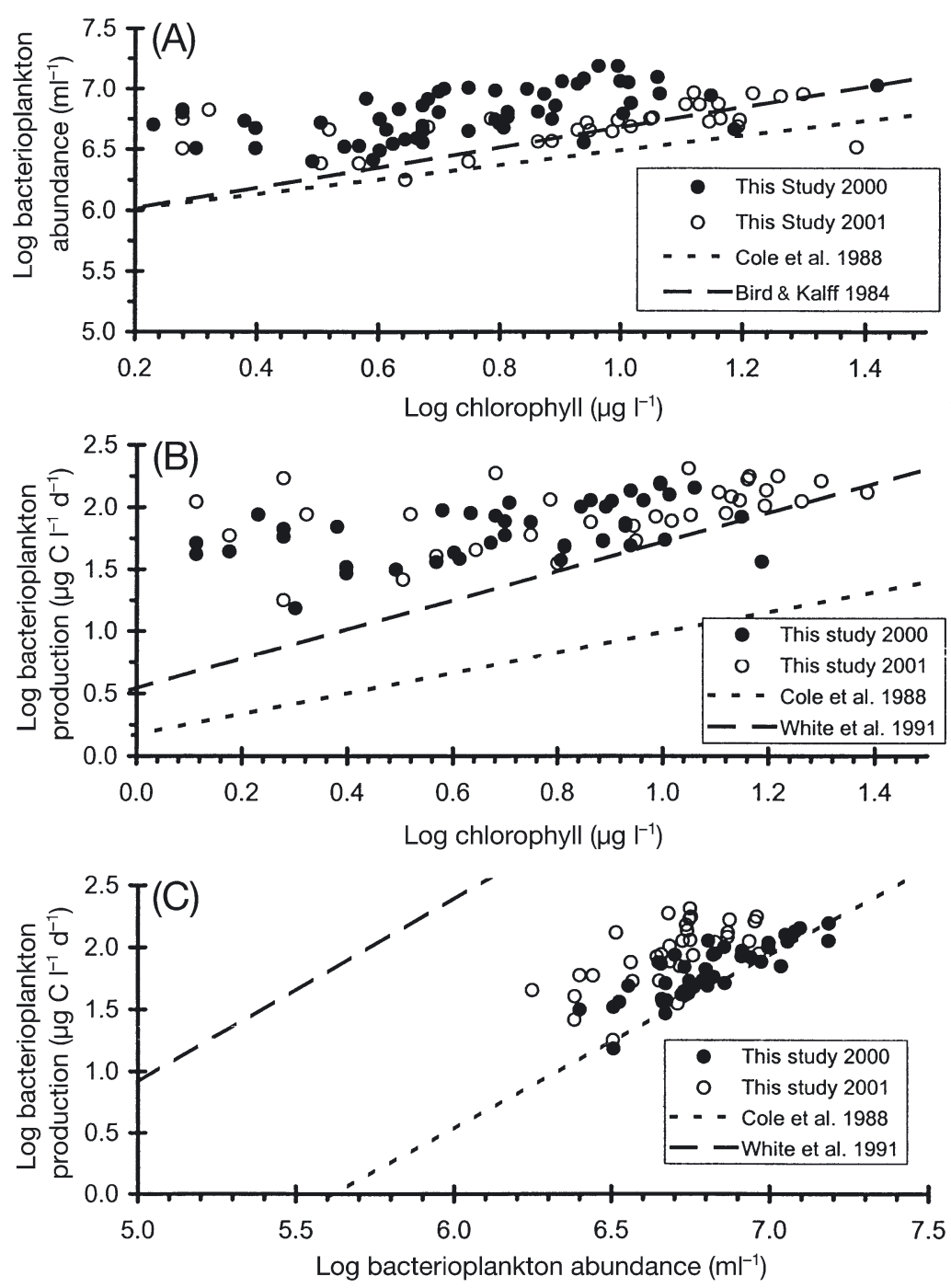

chl a concentrations were low. While correlations cannot denote causation, it is obvious that phytoplankton represent a critical substrate resource for bacterioplankton metabolism. It is also clear that the nature of linkage can be variable, and likely reflects the fact that many physiological and environmental factors act to modulate this linkage. Examples of such factors include bacterial growth efficiency, phytoplankton biomass:productivity ratios, organic matter quality (including the role of allochthonous carbon sources), trophic interactions and temperature regime. However, what appears conspicuous when examining the references that comprise the literature syntheses is the lack of data from warm subtropical regimes. Given the critical role of temperature in modulating physiological processes, the pattern observed in Pensacola Bay may not be so surprising. Future studies should focus on determining whether this empirical pattern is broadly representative of warmer environments.

Fig. 7. Relationships between phytoplankton and bacterioplankton variables and comparisons to widely cited literature-synthesis studies. (A) Bacterioplankton abundance versus chlorophyll a (chl a), (B) bacterioplankton production versus chl $a$ and (C) bacterioplankton production versus bacterioplankton abundance. The lines represent literature averages as indicated by the legend 


\section{CONCLUSIONS}

Bacterioplankton production rates were among the highest reported from the Gulf of Mexico area. Bacterioplankton bulk metabolism in Pensacola Bay exhibited strong seasonal dynamics that were largely attributable to increases in abundance during the summer. Specific growth rates, when adjusted to a constant temperature, exhibited a striking inter-annual pattern being lower during 2000 than 2001. These specific growth rates covaried with river flow, suggesting that bacterioplankton growth was dependent on freshwater flow. Bacterioplankton appeared substrate limited during 2000, likely due to reduced delivery of river-borne allochthonous carbon and inorganic nutrients; this limitation was alleviated during 2001, when normal river flow resumed. Comparisons with the literature suggest that Pensacola Bay had higher bacterial abundance and production than predicted from chl a concentration, which may be characteristic of warm, subtropical systems.

Acknowledgements. This study was made possible by the excellent field and lab support provided by E. M. Lores, E. M. Pasko, J. Patrick, R. Quarles, L. M. Smith and R. S. Stanley. Discussions with G. T DiDonato, A. R. Juhl and J. M. Caffrey helped clarify aspects of this work. W. Jeffrey and 2 anonymous reviewers made helpful comments on an earlier draft of the manuscript. Contribution No. 1173 US EPA, Gulf Breeze, FL, USA. Mention of trade names or commercial products does not constitute endorsement by the US EPA.

\section{LITERATURE CITED}

Alexander RB, Ludtke AS, Fitzgerald KK, Schertz TL (1996) Data from selected US Geological Survey national stream water-quality monitoring networks (WQN). United States Geological Survey, OFR 96-337, Reston, VA

Azam F, Fenchel T, Field JG, Gray JS, Meyer-Riel LA, Thingstad F (1983) Ecological role of water column microbes in the sea. Mar Ecol Prog Ser 10:257-263

Biddanda B, Opsahl S, Benner R (1994) Plankton respiration and carbon flux through bacterioplankton on the Louisiana shelf. Limnol Oceanogr 36:1259-1275

Bird DF, Kalff J (1984) Empirical relationships between bacterial abundance and chlorophyll concentrations in fresh and marine waters. Can J Fish Aquat Sci 41:1015-1023

Chin-Leo G, Benner R (1992) Enhanced bacterioplankton production and respiration at intermediate salinities in the Mississippi River plume. Mar Ecol Prog Ser 87:87-103

Chin-Leo G, Kirchman DL (1988) Estimating bacterial production in marine waters from the simultaneous incorporation of thymidine and leucine. Appl Environ Microbiol 54:1934-1939

Chrost RJ (1990) Microbial ectoenzymes in aquatic environments In: Overbeck J, Chrost RJ (eds) Aquatic microbial ecology: biochemical and molecular approaches. Springer Verlag, New York, p 47-78

Coffin RB, Connolly JP (1997) Bacteria and heterotrophic microflagellate production in the Santa Rosa Sound, Florida. Hydrobiologia 353:53-61

Cole JJ, Findlay S, Pace ML (1988) Bacterial production in fresh and saltwater ecosystems: a cross-system overview. Mar Ecol Prog Ser 43:1-10

Cotner JB Jr, Gardner WS (1993) Heterotrophic bacterial mediation of ammonium and dissolved free amino acid flux in the Mississippi River plume. Mar Ecol Prog Ser 93: $75-87$

Ducklow HW (2000) Bacterial production and biomass in the oceans. In: Kirchman DL (ed) Microbial ecology of the oceans. Wiley-Liss, New York, p 85-120

Ducklow HW, Carlson CA (1992) Oceanic bacterial production In: Marshall KC (ed) Advances in microbial ecology, Vol 12. Plenum Press, New York, p 113-181

Findlay S, Pace ML, Lints D, Cole JJ, Caraco NF, Peierls B (1991) Weak coupling of bacterial and algal production in a heterotrophic system: the Hudson River estuary. Limnol Oceanogr 36:268-278

Hollibaugh JT, Wong PS (1992) Ethanol-extractable substrate pools and the incorporation of thymidine, L-leucine and other substrates by bacterioplankton. Can J Microbiol 38: 605-613

Hollibaugh JT, Wong PS (1996) Distribution and activity of bacterioplankton In: Hollibaugh JT (ed) San Francisco Bay: the ecosystem. Pacific Division, American Association for the Advancement of Science, San Francisco, p 263-288

Hoppe HG (1983) Significance of exoenzyme activities in the ecology of brackish water: measurements by means of methylumbelliferyl-substrates. Mar Ecol Prog Ser 11: 299-308

Jeffrey SW, Mantoura RFC, Wright SW (1997) Phytoplankton pigments in oceanography: guidelines to modern methods. UNESCO Publishing, Paris

Karner M, Fuks D, Herndl GJ (1992) Bacterial activity along a trophic gradient. Microb Ecol 23:243-257

Kirchman DL (2000) Microbial ecology of the oceans. WileyLiss, New York

Kirchman D, Soto Y, Van Wambeck F, Bianchi M (1989) Bacterial production in the Rhone River plume: effect of mixing on relationships among microbial assemblages. Mar Ecol Prog Ser 53:267-275

Lee S, Fuhrman JA (1987) Relationships between biovolume and biomass of naturally derived marine bacterioplankton. Appl Environ Microbiol 53:1298-1303

Li WKW, Dickie PM (1987) Temperature characteristics of photosynthetic and heterotrophic activities: seasonal variations in temperate microbial plankton. Appl Environ Microbiol 53:2282-2295

Meybeck (1982) Carbon, nitrogen and phosphorus transport by world rivers. Am J Sci 282:401-450

Muller-Niklas G, Schuster S, Kaltenbock E, Herndl GJ (1994) Organic content and bacterial metabolism in amorphous aggregations of the northern Adriatic Sea. Limnol Oceanogr 39:58-68

Munster U (1991) Extracellular enzyme activity in eutrophic and polyhumic lakes. In: Chrost RJ (ed) Microbial enzymes in aquatic environments. Springer Verlag, New York, p 96-122

Murrell MC, Hollibaugh JT, Silver MW, Wong PS (1999) Bacterioplankton dynamics in northern San Francisco Bay: role of particle association and seasonal freshwater flow. Limnol Oceanogr 44:295-308

NRC (National Research Council) (2000) Clean coastal waters: understanding and reducing the effects of nutrient pollution. National Academy Press, Washington, DC

Olinger LW, Rogers RG, Fore PL, Todd RL, Mullins BL, Bisterfeld F, Wise LA (1975) Environmental and recovery studies of Escambia Bay and the Pensacola Bay system, Florida. 
Report 904/9-76-016, US Environmental Protection Agency, Surveillance and Analysis Division, Atlanta, GA Painchaud J, Therriault JC (1989) Relationships between bacteria, phytoplankton and particulate organic carbon in the upper St Lawrence estuary. Mar Ecol Prog Ser 56:301-311

Pakulski JD, Benner R, Amon R, Eadie B, Whitledge T (1995) Community metabolism and nutrient cycling in the Mississippi River plume: evidence for intense nitrification at intermediate salinities. Mar Ecol Prog Ser 117:207-218

Pomeroy LR, Wiebe WJ (2001) Temperature and substrates as interacting limiting factors for marine heterotrophic bacteria. Aquat Microb Ecol 23:187-204

Pomeroy LR, Sheldon JE, Sheldon WM Jr, Peters F (1995) Limits to growth and respiration of bacterioplankton in the Gulf of Mexico. Mar Ecol Prog Ser 117:259-268

Porter KG, Feig YS (1980) The use of DAPI for identifying and counting aquatic microflora. Limnol Oceanogr 25:943-948

Redfield AC (1958) The biological control of chemical factors in the environment. Am Sci 46:205-221

Rosso AL, Azam F (1987) Proteolytic activity in coastal oceanic waters: depth distribution and relationship to bacterial populations. Mar Ecol Prog Ser 41:231-240

Schroeder WW, Wiseman WJ (1999) Geology and hydrodynamics of Gulf of Mexico Estuaries. In: Bianchi TS, Pennock JR, Twilley RR (eds) Biogeochemistry of Gulf of Mexico estuaries. Wiley-Liss, New York, p 3-28

Editorial responsibility: David Karl, Honolulu, Hawaii, USA
Simon M, Azam F (1989) Protein content and protein synthesis rates of planktonic marine bacteria. Mar Ecol Prog Ser 51:201-213

Smith DC, Azam F (1992) A simple, economical method for measuring bacterial protein synthesis rates in seawater using ${ }^{3} \mathrm{H}$-leucine. Mar Microb Food Webs 6:107-114

Solis RS, Powell GL (1999) Hydrography, mixing characteristics, and residence times of Gulf of Mexico estuaries. In: Bianchi TS, Pennock JR, Twilley RR (eds) Biogeochemistry of Gulf of Mexico estuaries. Wiley-Liss, New York, p 29-62

Somville M (1984) Measurement and study of substrate specificity of exoglucosidase activity in eutrophic water. Appl Environ Microbiol 48:1181-1185

Somville M, Billen G (1983) A method for determining exoproteolytic activity in natural waters. Limnol Oceanogr 28: 190-193

Vives-Rego J, Billen G, Fontigny A, Somville M (1985) Free and attached proteolytic activity in water environments. Mar Ecol Prog Ser 21:245-249

Welschmeyer NA (1994) Fluorometric analysis of chl $a$ in the presence of chl $b$ and phaeopigments. Limnol Oceanogr 39:1985-1992

White PA, Kalff J, Rasmussen JB, Gasol JM (1991) The effect of temperature and algal biomass on bacterial production and specific growth rate in freshwater and marine habitats. Microb Ecol 21:99-118

Submitted: October 5, 2002; Accepted: March 4, 2003

Proofs received from author(s): May 7, 2003 